Bisset, K. A. \& Hale, C. M. F. (1951). J. gen. Microbiol. 5, 592-595.

\title{
The Production of Swarmers in Rhizobium spp.
}

\author{
By K. A. BISSET and C. M. F. HALE \\ Department of Bacteriology, University of Birmingham
}

SUMMARY: In certain strains of Rhizobium spp., tiny spherical swarmers, with a central nucleus and one or occasionally two flagella, are released from the cell lumen of specialized large bacilli, the 'barred' forms, of which the 'bars' are modified crosswalls. The swarmers exhibit appearances suggestive of conjugation.

In other strains true swarmers are not produced; their function is performed by small motile cells produced by normal cell division.

The outline of the life cycle of Rhizobium spp. is well known, but some controversy exists upon the mode of formation of the small swarmer elements. The view of Thornton \& Gangulee (1926) and others, that these arise by the break-up of the 'barred' rods, of which each stainable band represents a single swarmer cell, appears to be widely accepted; that of Lewis (1938), that they arise by the continued process of cell division, probably refers, as will be shown, to the production of small, motile elements in strains which do not form true swarmers, whereas the latter originate within the barred bacilli and are released by the rupture of the cell wall. This type of reproduction is found, in a variety of comparable forms, in many bacterial groups (Bisset, 1950).

\section{METHODS}

Thirty-two strains of Rhizobium spp. were examined. Twenty-seven were newly isolated from root-nodules of cultivated peas and beans, everlasting sweet-pea, wild vetch, lupin and various species of clover. Five were laboratory cultures.

Initial cultures were made by sterilizing the surface of the root-nodules with $\mathbf{0} \cdot \mathbf{1} \%$ mercuric chloride, crushing them between sterile slides, and inoculating upon nutrient agar containing $\mathbf{0 \cdot 3} \%$ Yeastrel.

Smears were stained by Gram's method, by acid-Giemsa for nuclear structures, by tannic acid violet for cell walls (see Bisset, 1950), and by silver impregnation for flagella. Flagella were also demonstrated by electron microscopy.

\section{OBSERVATIONS}

General morphology. At most stages of culture the majority of strains consisted of small unicellular bacteria (PI. 2, fig. 16), either motile or non-motile, but some young cultures, especially those from lupin and everlasting sweet-pea, contained large, septate bacilli, with from four to ten or more cells (PI. 1, fig. 4; Pl. 2, figs. 11, 12). The morphology of the bacteroids found in the root-nodules will be described in a separate study.

Flagella. Bacteroids and other stages within the plant were devoid of flagella. The large bacilli were peritrichously flagellate (Pl. 1, fig. 6). The swarmers had a single flagellum or, less frequently, two flagella (Pl. 2, figs. 8-10 and 14). The small motile bacteria, in strains which did not produce swarmers, 
had four or five flagella arranged in a rather haphazard manner, polar, peritrichous or in a tuft at one side of the cell (Pl. 2, fig. 16).

Production of swarmers. In strains which did not produce true swarmers, many cells in the motile stage were so small as to resemble them, but were much less regular in their morphology. They appeared to be formed by the normal process of cell division from larger cells, and a complete series of intermediate stages could often be seen in a single culture. This condition was typical of strains from cultivated peas, beans and clovers, although true swarmers may occasionally have been produced by some of these.

In the strains from lupins, sweet-peas and vetches the swarmers were produced from barred bacilli of the kind so frequently described in the past (Pl. 1, figs. 1, 2). These occurred in cultures of the large multicellular bacilli (Pl. 1, fig. 4), which they resembled in most respects, although the specialized reproductive bacilli were slightly larger than the vegetative bacilli (cf. Pl. 1, figs. 1, 4). The barred appearance was due to an aggregation of stainable material upon the interior cross-walls of the bacilli. The tiny coccoid swarmers were produced from the lumen of these cells and emerged by the rupture of the cell wall (Pl. 1, figs. 1, 2; Pl. 2, figs. 11, 12). It is reasonable to assume that this stainable material is concerned with the formation of the cell constituents of the swarmers. By electron microscopy this appearance of a thickened cell wall surrounding a hollow lumen was occasionally seen (Pl. 1, fig. 3). In both electron and photomicrographs these mother cells appeared as though softened and, eventually, empty and disrupted (Pl. 1, figs. 1, 6 and 7; Pl. 2, figs. 11, 12). In nearly all micrographs swarmers were seen attached to, or emerging through, the cell wall of the mother bacillus (Pl. 1, figs. 5-7; Pl. 2, fig. 8).

The swarmers frequently appeared in arrangements suggestive of conjugation (Pl. 1, fig. 1; Pl. 2, figs. 13, 14). The alternative explanation, that these cells were dividing instead of fusing, is not in accordance with the configuration of the nuclear elements and of the flagella; the former being more closely fused than the cytoplasm, whereas the division of the nucleus normally precedes that of the remainder of the cell; the latter being equally well developed upon both cells. In fact the swarmers, as such, did not appear to reproduce, but rapidly assumed the form of tiny bacilli, each with from one to three flagella (Pl. 2, figs. 11, 12 and 15), which grew up to form a new generation of vegetative bacteria, or which, alternatively, were capable of infecting the root-hairs of susceptible plants.

\section{DISCUSSION}

The appearances seen in both electron and photomicrographs of the production of swarmers in Rhizobium spp. do not support either of the accepted theories of the mechanism of this process. It is not true that each stainable band upon the barred bacilli represents a single swarmer, nor that these bacilli fragment to produce the swarmers. They are released from the relatively lightly stained cell lumen between the bands, which appear to be modified secretory cell walls (Fig. 1).

It is true that small motile cells are produced by the normal processes of cell 
division in certain strains of Rhizobium spp., but these are not swarmers, although they may perform the same function.

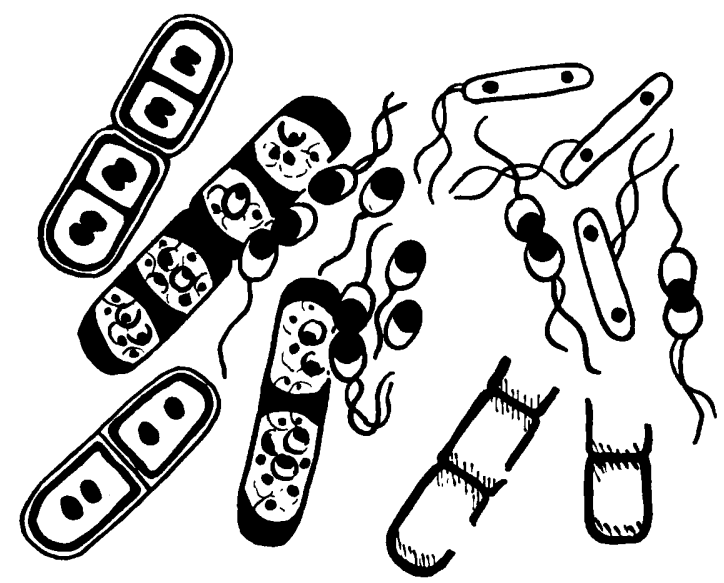

Fig. 1. Production of swarmers from the cell lumen of the large 'barred' bacilli. The bars are specialized cross-walls, and the swarmers are released by rupture of the cell wall. They show signs of conjugation and are rapidly transformed into small rods.

The independent occurrence of these two methods of producing small motile cells serves to clarify the divergent theories which have been suggested to explain the appearance of swarmers. It is especially significant that true swarmers are less readily produced by the strains of bacteria found in association with the best-known and most important leguminous crops.

\section{REFERENCES}

Bisset, K. A. (1950). The Cytology and Life History of Bacteria. Edinburgh: Livingstone.

LEwis, I. M. (1938). Cell inclusions and life cycle of Rhizobia. J. Bact. 35, 573.

Thornton, H. G. \& Gangulee, N. (1926). The life cycle of the nodule organism Bacillus radicicola (Beij.) in soil, and its relation to the infection of the host plant. Proc. roy. Soc. B, 99, 427.

\section{EXPLANATION OF PLATES}

(All figures except Pl. 2, fig. 16, are of a strain of Rhizobium derived from lupin. Figs. 1, 2, 4, 11 and 12 are photomicrographs, the remainder electron micrographs.)

\section{Plate 1}

Figs. 1, 2. Release of swarmers from large 'barred' bacilli. The bars are obviously modified cross-walls. The arrows indicate the apparent fusion of swarmers. In one bacillus the outer wall is softened and disrupted. Acid-Giemsa. $\times 3000$.

Fig. 3. Barred bacillus by electron microscopy. Here also the identity of the bars with crosswalls is apparent. $\times 16,000$.

Fig. 4. Large multicellular vegetative bacilli. Acid-Giemsa. $\times 3000$.

Figs. 5-7. Release of swarmers. In fig. 6 the flagella of the bacillus are seen. It is soft and electron transparent $(\times 10,000)$. In figs. 5 and 7 collapsed and disrupted bacilli are seen $(\times 50,000)$. In all three swarmers are attached to, or emerging through, the walls of the bacilli. 
Journal of General Microbiology, Vol. 5, No. 3
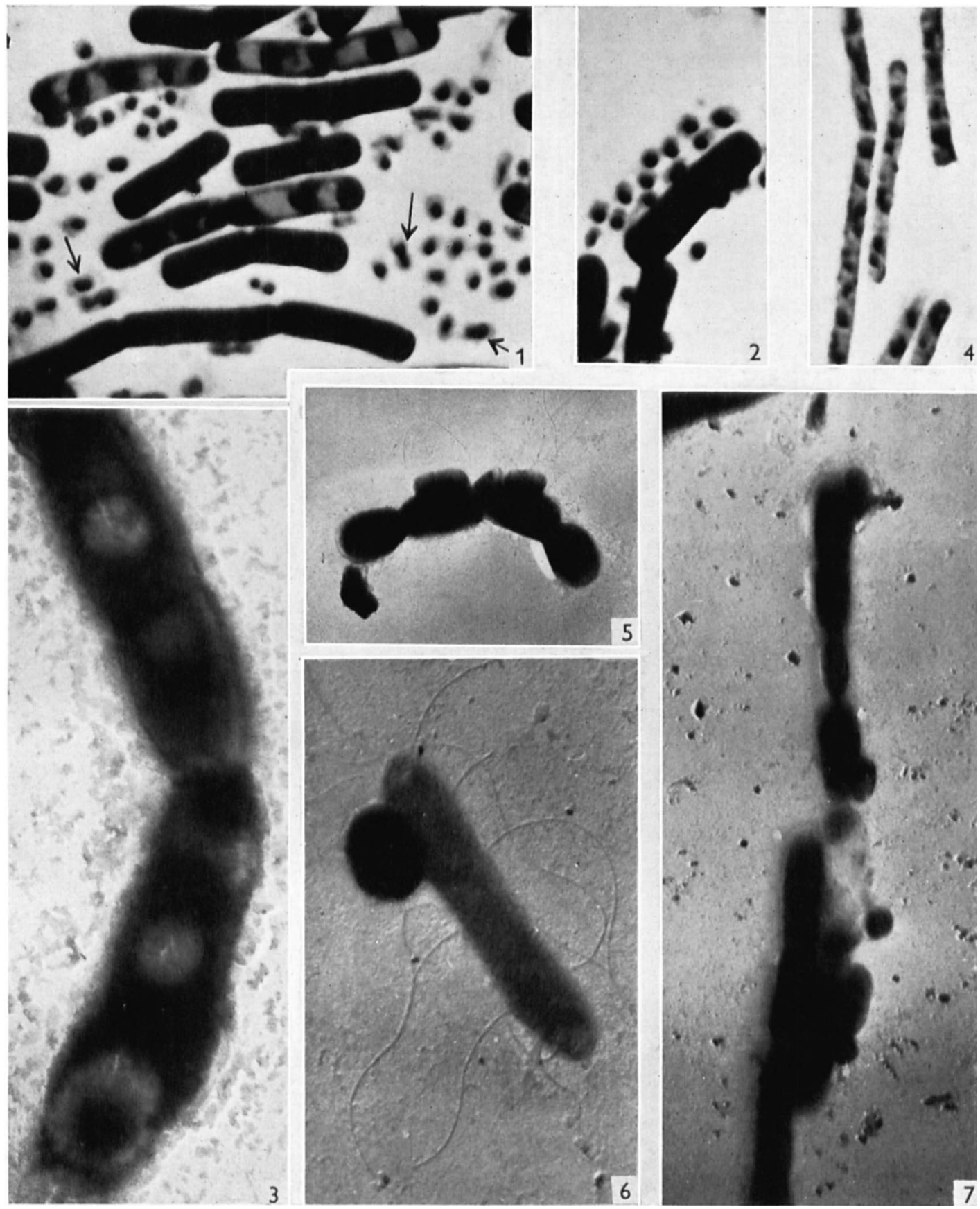

Figs. 1-7

K. A. Bisset and C. M. F. Hale--Swarming in Rhizobivm. Plate 1 
Journal of General Microbiology, Vol. 5, No. 3

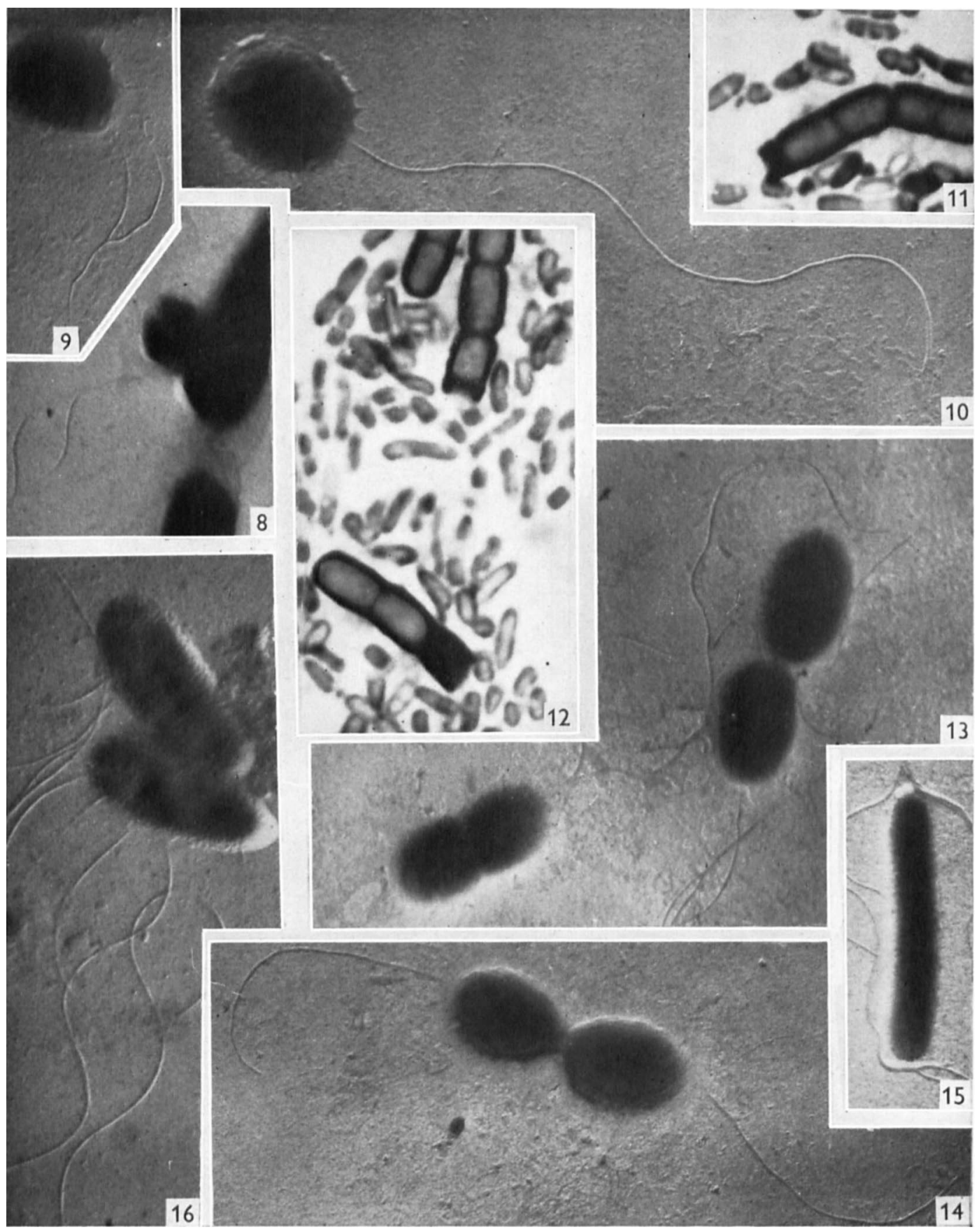

Figs. 8-16

K. A. Bisset and C. M. F. Hale-Swarming in Rhizobium. Plate 2 


\section{Plate 2}

Figs. 8, 9. Swarmers, each with two flagella. $\times 10,000$ and $\times 16,000$ respectively.

Fig. 10. Swarmer with single flagellum. $\times 20,000$.

Figs. 11, 12. Broken cell walls of bacilli, showing cross-walls; swarmers mainly transformed into small rods. Tannic-acid-violet. $\times \mathbf{3 0 0 0}$.

Figs. 13, 14. Swarmers apparently in various stages of fusion. $\times 16,000$.

Fig. 15. Swarmer transformed into small rod. $\times 16,000$.

Fig. 16. Rhizobium from small, white clover. Small cells, actively motile by lateral tufts of flagella. $\times 16,000$.

(Received 28 February 1951) 